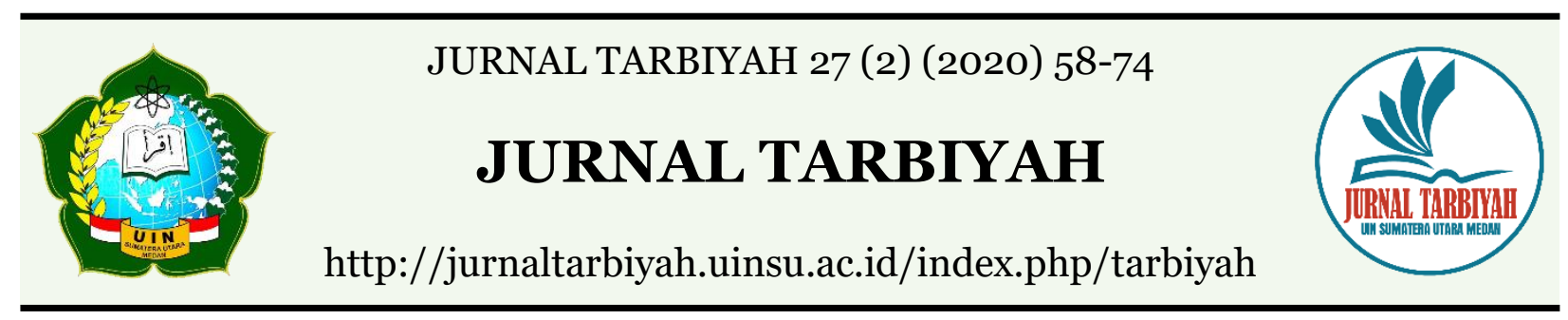

\title{
FACTORS AFFECTING STUDENTS' THESIS COMPLETION ON DEPARTMENT OF MANAGEMENT STIE MIKROSKIL
}

\author{
Ella Silvana Ginting', Apren Halomoan Hutasoit ${ }^{2}$ \\ 1,2 STIE Mikroskil, Medan, Indonesia \\ Email: ella fa86@yahoo.com ${ }^{1}$ \\ apren.halomoan@mikroskil.ac.id ${ }^{2}$
}

DOI : 10.30829/tar.v27i2.843

Accepted: October 15th, 2020. Approved: December 25th, 2020. Published: December 31th, 2020

\begin{abstract}
This study is aimed to investigate the factors that influence the completion of students' final task, thesis. The research is causal comparative research which the data were obtained by directly surveying respondents through questionnaire. The population in this study were students who finishing their final task, who in semester 8 students students, with total sample size of 67 . From the results of the hypothesis analysis simultaneously, a significant value was obtained of 0.000 , which means that motivation to graduate on time, the ability to write scientific papers, and the quality of assignment guidance final possess effect on the completion of student final assignments. Partial analysis obtained a significant value of the motivation variable of 0.012 , the variable of the ability to write scientific papers of 0.018 , and the variable of quality of guidance of 0.000 , which means that partially motivation, the ability to write scientific papers, and the quality of final assignment guidance stimulate bring effect on the completion of students' final tasks.
\end{abstract}

Keywords: motivation, writing ability, guidance quality, final task 


\section{INTRODUCTION}

A resource is a matter that considered to bring the potential to produce output. Humans are one of the resources owned by a country that will be able to provide the maximum contribution to the development of the country. Besides, in order to implement the development, definelty the establishment cannot be separated from the quality of human resources. In this case, the human resources definetily, in this context, are human resources with hiqh quality. Quality human resources can be measured from several aspects, such as from the level of education and also from their health. According to the Law of the Republic of Indonesia Number 20 of 2003 Chapter 1 General Provisions Article 1 states that: "Education means conscious and well-planned effort in creating a learning environment and learning process so that learners will be able to develop their full potential for acquiring spiritual and religious strengths, develop self-control, personality, intelligence, morals and noble character and skills that one needs for him/herself, for the community, for the nation, and for the State."Education is very important for a country in case that it will be able to provide an overview of a developed country. One of the determinants of a country's progress is measured from the quality of its education. According to the Law of the Republic of Indonesia Number 20 of 2003 Chapter 1 General Article Provisions 3, mentions that: "The National Education functions to develop the capability, character, and civilization of the nation for enhancing its intellectual capacity, and is aimed at developing learners'potentials so that they become persons imbued with human values who are faithful and pious to one and only God; who possess morals and noble character; who are healthy, knowledgeable, competent, creative, independent; and as citizens, are democratic and responsible."

Recognizing the goals and functions of national education, educational institutions are required to implement very large task. Educational institutions, especially higher education or higher education institutions (university), posses a duty to maintain the quality of graduates and provide provisions for their graduates to be able to compete in the current global era. Therefore, graduates from higher education are required to mastery the knowledge, skills (soft skills and hard skills), and attitudes.

In completing the final project (TA), students should have the motivation to graduate, and even in this case the motivation is the stimulataion to graduate on time. Motivation is the support from students mind to be willing to undertake the final project completion process. As matter of facts, with the motivation on theirselves, it will be able to make it easier for them to complete their final assignments and complete their study 
process. However, according to the results of the researcher's analysis, there are many STIE Mikroskil students, especially those in the Management Study Program, who lack motivation on theirselves. There are still number of students who have not been able to complete their final assignments on time. Students are remain stalling for time to improve their final assignments . In this case, it can be observed that some of the students studying while working with different types of work, where some of them are often less able to spare their time to focus more on completing their final project. With different loads and responsibilities, it is not uncommon for them to obstruct the completion their students' final assignments. This also cause the schedule of guidance provided by the supervisor is not utilized by students properly.

Furthermore, what students should mastert in order to complete their final assignment (TA) is based on the student's ability to write scientific papers. The ability to write scientific papers will be a very important factor, due to the fact that if students are able and willing to write, the final project (TA) will be completed. However, in the current condition, the researcher found the facts that there are still many Department of Management students who lack the ability to write scientific papers. From these findings, students stated that there are still many difficulties in understanding the writing of scientific papers. According to Kuncoro (2013), scientific work is a formal and systematic application of the scientific method to study and answer problems. Referring to this understanding, there are many students who still do not understan the concept of writing a work to be written. Moreover, the problem that often occurs is that students have not been able to find a study of the problem to be studied. When the interview was conducted, several students said that the lack of understanding how to start writing a final project was the main obstacle so that it was often found that the determination of variables based on references to the journals read and the main determination of an object of research was based on the allowance given by the company to research at the company. This is very different from the procedure for determining the actual title. Because of this lack of understanding, the slow progress of students' final assignments occurred. Another thing found was that some students did not understand what was the basis for how to write phenomena on the background, so that the description of phenomena was generally based on student understanding, not based on the indicators presented on theoretical studies.

Furthermore, responding to this fact, students also found a lack of understanding of the methodology used in research, causing an incorrect understanding of the minimum population size. So, when the thesis has been conducting, the research should be stopped 
in case the population used has not met the research standards according to the established method. In this case, it was also found that most of the students in the previous final project did not read the guidelines provided so that they received a revision from the supervisor regarding the format of writing, punctuation, and spelling.

Furthermore, what students should have in completing their final assignments is quality during the final assignment guidance process. Final assignment guidance is defined as an activity carried out between students and their supervisors. In this case, the researchers found that when they were about to carry out the guidance process, many students were afraid to come to their supervisor's room. Besides they are afraid and ashamed, they also feel the lack of benefits obtained by students when carrying out the guidance process. In addition, students have the perception that final assignment guidance is scary for students. They are afraid that when the guidance process of the final assignment, the student's writing will be scribbled by the supervisor. This is a phenomenon among students who are completing their final assignments. In this case, based on interviews with students, it was found that the supervisors give less attention to the quality of the writing than the students, where in this case the students themselves needed further guidance on how to write the correct final project. In this case, information is also obtained, that the information provided by the supervisor is not in accordance with the needs required by students due to the limited discussion time provided by the supervisor.

\section{METHODS}

By the research classification according to the method, the type of research in this study is comparative causal research. Comparative causal research is a type of research in which research is conducted to determine the causes or reasons for differences in behavior or status of groups or individuals (Darmadi, 2011). The approach used in this research is a quantitative approach. The quantitative approach is used to examine data in the form of numbers that are processed and analyzed in the form of statistical analysis, namely in a questionnaire distributed about the factors that affect the completion of the final project of STIE Mikroskil Management Department students.

The data collection technique in this research is distributing questionnaires to students. Questionnaire is a data collection technique that is carried out by giving a set of written statements to respondents to answer them (Sugiyono, 2013). In this study, questionnaires were distributed to students with alternative values using a Likert scale. 
This research was conducted at STIE Mikroskil with the population studied were students of the 2016 class of Management Study Programs who were conducting their final project. The total totals of 2016 class students who have prepared their final assignments (TA) are as follows:

Table 1 Number of Sample

\begin{tabular}{|c|c|}
\hline $\begin{array}{c}\text { Class According to Amount of } \\
\text { Specialization }\end{array}$ & Jumlah \\
\hline MB-A Morning & 25 Students \\
\hline MB-A Evening & 36 Students \\
\hline MP-A Evening & 6 Students \\
\hline Total & 67 Students \\
\hline
\end{tabular}

Source: Department of Management STIE Mikroskil (2020)

In this study, questionnaires were distributed to students and then recollected. Furthermore, the questionnaires that have been collected were tested for data quality by testing the validity and reliability to determine the accuracy of the data that the researcher wants to obtain. In this study the researcher analyzed the data by presenting the data that has been obtained based on a questionnaire, and then being analyzed by using descriptive statistical analysis. Descriptive statistical analysis was used to determine the characteristics or general description of the respondents under study. Furthermore, after descriptive analysis was carried out, the next step was to conducted multiple linear regression analysis. Multiple linear regression analysis was used to measure the intensity of the relationship between two or more variables and make predictions of the $\mathrm{Y}$ value estimate for X (Sugiyono, 2013).

\section{RESULT AND DISCUSSION}

Tabel 2 Variable Descriptive Statistic of Final Task Completion

\section{Statistics}

\begin{tabular}{lllllll}
\hline & & $\begin{array}{l}\text { Tittle } \\
\text { Approval }\end{array}$ & $\begin{array}{l}\text { Draft } \\
\text { Proposal }\end{array}$ & $\begin{array}{l}\text { Review } \\
\text { Proposal }\end{array}$ & $\begin{array}{l}\text { Data } \\
\text { Presentation }\end{array}$ & $\begin{array}{l}\text { Final } \\
\text { Examination }\end{array}$ \\
\hline \multirow{2}{*}{ V } & Valid & 61 & 61 & 61 & 61 & 61 \\
\cline { 2 - 7 } & Missing & $\mathrm{O}$ & $\mathrm{O}$ & $\mathrm{O}$ & $\mathrm{O}$ & $\mathrm{O}$ \\
\hline Mean & $\mathbf{3 . 7 3 7 7}$ & $\mathbf{3 . 4 5 9 0}$ & $\mathbf{3 . 6 0 6 6}$ & $\mathbf{3 . 4 4 2 6}$ & $\mathbf{3 . 6 0 6 6}$ \\
\hline
\end{tabular}

Source: Research Result 2020 
The statistical results shown in Table 2 show that the thesis title approval indicator obtained the answers from the respondents, for an average value of 3.73. Furthermore, for the indicator for drafting the proposal, the average value is 3.45 , the proposal review indicator obtained an average value of 3.60. Research indicators and data collection obtained an average value of 3.44, the final exam test indicator obtained an average value of 3.60. From the results of the average value of the respondents' answers to all variables of final assignment preparation was obtained at 3.56. From the results of the average value of the respondents' answers, it can be concluded that the respondents expressed their disagreement with all indicators of the final assignment completion variable in this study.

Table 3 Variable Descriptive Statistic of Motivation to Graduate on Time

\begin{tabular}{|c|c|c|c|c|c|}
\hline \multicolumn{6}{|c|}{ Statistics } \\
\hline & & \multicolumn{3}{|c|}{ Quick to Get } & \multirow[b]{2}{*}{ perseverance } \\
\hline & & Job & Pride & Award & \\
\hline \multirow[t]{2}{*}{$\mathrm{N}$} & Valid & 61 & 61 & 61 & 61 \\
\hline & Missing & $\mathrm{O}$ & 0 & 0 & 0 \\
\hline \multicolumn{2}{|c|}{ Mean } & $\mathbf{3 . 8 1 9 7}$ & $\mathbf{3 \cdot 7 3 7 7}$ & 3.1148 & $\mathbf{3 \cdot 3 9 3 4}$ \\
\hline
\end{tabular}

Source: Research Result 2020

The statistical results shown in Table 3 show that the average value of respondents 'answers to the indicator of wanting to quickly get a job is 3.81, the indicator of pride was obtained by the average value of respondents' answers to 3.73. The indicator of the award obtained the average value of respondents 'answers was 3.11, and the indicator of resilience and perseverance obtained the average value of respondents' answers of 3.39.

Table 4 Variable Descriptive Statistic of Skill in Paper Writing

\section{Statistics}

\begin{tabular}{|c|c|c|c|c|c|c|c|}
\hline & \multicolumn{2}{|l|}{ Research } & \multicolumn{2}{|l|}{ Compatibility } & \multirow[b]{2}{*}{ Diction } & \multirow[b]{2}{*}{ Punctuation } \\
\hline & & $\begin{array}{l}\text { Paper } \\
\text { Knowledge }\end{array}$ & $\begin{array}{l}\text { Writing } \\
\text { Experience }\end{array}$ & $\begin{array}{l}\text { of title and } \\
\text { content }\end{array}$ & $\begin{array}{l}\text { Ideas } \\
\text { Shared }\end{array}$ & & \\
\hline \multirow[t]{2}{*}{$\overline{\mathrm{N}}$} & Valid & 61 & 61 & 61 & 61 & 61 & 61 \\
\hline & Missing & $\mathrm{O}$ & $\mathrm{O}$ & O & $\mathrm{O}$ & O & $\mathrm{O}$ \\
\hline & & 3.0984 & 3.1639 & 3.5410 & 3.4590 & $\mathbf{3 . 5 7 3 8}$ & $3 \cdot 5082$ \\
\hline
\end{tabular}

Source: Research Result 2020 
The statistical results shown in table 4 for the variable writing ability of scientific papers obtained an average value for the indicator of knowledge of scientific papers is 3.09. The indicator of the experience of writing scientific papers obtained that the average value of respondents 'answers was 3.16, the indicator of the compatibility of the title with the content of scientific papers obtained the average value of respondents' answers of 3.54. Indicator of ideas put forward in scientific papers, the average value of respondents 'answers is 3.45, the indicator of choice of using the right words in scientific papers is that the average value of respondents' answers is 3.57, and the indicator of understanding punctuation in scientific papers the average value of respondents' answers is 3.50 .

\section{Table 5 Variable Descriptive Statistic of Quality of Research Paper Guidance}

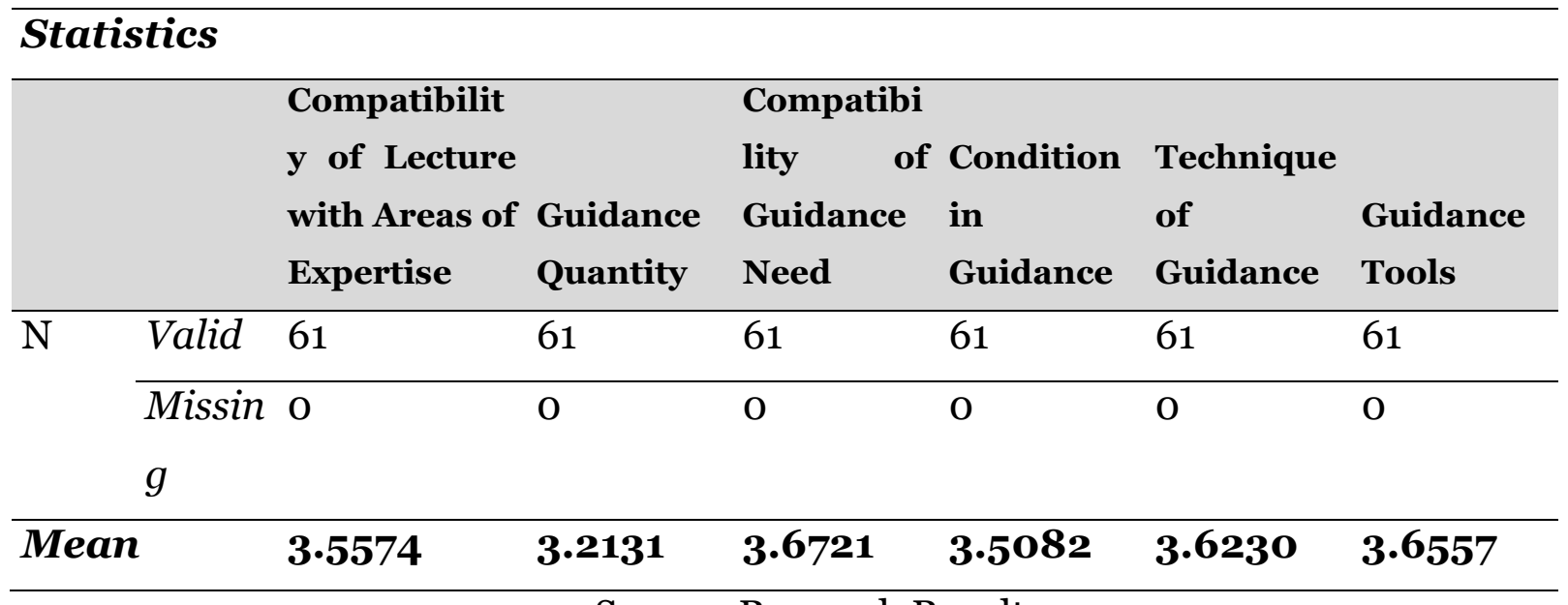

Source: Research Result 2020

The statistical results of the variable of the quality of final assignment guidance (TA) can be seen in Table 5, which shows that the average value obtained from the indicator of the suitability of the lecturer with the field of expertise is 3.55 . The indicator of the quantity of guidance obtained by the average value of the respondents 'answers is 3.21 , the indicators of suitability of the guidance needs obtained the average value of the respondents' answers of 3.67. Furthermore, the situation indicator when the guidance was obtained the average value of the respondents' answers is 3.50 , the guidance technique indicators obtained the average value of the respondents' answers of 3.62 and the indicators of equipment to support the needs of guidance obtained the average value of respondents' answers of 3.65 . 
Tabel 6 Validity Test

\begin{tabular}{|l|l|}
\hline Variabel & HASIL \\
\hline Final Project Completion & All indicators are valid \\
\hline Motivation to Pass on Time & All indicators are valid \\
\hline Ability to Write Scientific Papers & All indicators are valid \\
\hline Quality of Final Project Guidance & All indicators are valid \\
\hline
\end{tabular}

Source: Processed Data (2020)

From all the variables in the study, it was found that all indicators in this study were valid and could be used as an instrument of this research.

Table 7 All Variable Reliability Result

\begin{tabular}{llll}
\hline Variable & $\begin{array}{l}\text { Cronbach } \\
\text { Alpha }\end{array}$ & $\begin{array}{l}\text { Measurement } \\
\text { Scale }\end{array}$ & $\begin{array}{l}\text { Result } \\
\text { Information }\end{array}$ \\
\hline Final Task Completion & 0,912 & 0,70 & Perfect \\
\hline Motivation to Graduate On Time & 0,754 & 0,70 & High \\
\hline Skill in Writing scientific research & 0,897 & 0,70 & High \\
\hline Quality of Research Paper Guidance & 0,888 & 0,70 & High
\end{tabular}

\section{Source: Processed Data (2020)}

From the statistical results obtained in Table 7 , it can be seen that the final assignment completion variable is declared reliable because the Cronbach alpha value is higher than 0.70 . The motivation variable to pass on time was declared reliable because the Cronbach alpha value was 0.754 , higher than 0.70 . The variable of the ability to write scientific papers obtained a Cronbach alpha value of 0.897, higher than 0.70. And then on the variable of the quality of the final assignment guidance, the Cronbach alpha value is 0.888 , higher than 0.70 . So it can be concluded from all the variables in this study have been declared reliable and suitable for use as an instrument. 
Table 8 Analysis of Multicollinearity

\begin{tabular}{|c|c|c|c|}
\hline \multicolumn{4}{|c|}{ Coefficients $^{a}$} \\
\hline \multirow{2}{*}{\multicolumn{2}{|c|}{ Model }} & \multicolumn{2}{|c|}{ Collinearity Statistics } \\
\hline & & Tolerance & $V I F$ \\
\hline \multirow[t]{4}{*}{1} & (Constant) & & \\
\hline & Motivation to Graduate on Time & .386 & 2.592 \\
\hline & Skills in Writing scientific research & .279 & 3.579 \\
\hline & Final Task Guidance Quality & .241 & 4.145 \\
\hline
\end{tabular}

a. Dependent Variable: Final Task Completion

Source: Processed Data (2020)

From the results of the multi-collinearity statistical analysis in terms of testing the feasibility of the model in this study, it can be seen in table 8 that the statistical value of the tolerance variable for the motivation variable to graduate on time is $0.386>0.1$ and the VIF value is 2.592 not more than 10 , which means it is free from multicollinearity indications. Furthermore, the tolerance value for the variable writing capability of scientific papers is 0.279 higher than 0.1 and the VIF value of 3.579 is not more than 10, which means that the variable writing capability of scientific papers is free from multicollinearity indications. The statistical tolerance value on the variable of the quality of the final assignment guidance is $0.241>0.1$ and the VIF value is 4.145 , not more than 10 , which means that the variable of the quality of the final assignment guidance is free from multicollinearity indications. So it can be concluded that the model in this study fulfills the classical assumption rules.

Tabel 9 Analisys of Normality

\section{One-Sample Kolmogorov-Smirnov Test}

\begin{tabular}{lll}
\hline & & Unstandardized Residual \\
\hline $\mathrm{N}$ & & 61 \\
\hline Normal Parameters ${ }^{a, b}$ & Mean & .0000000 \\
\cline { 2 - 3 } & Std. Deviation & .43565672 \\
\hline Most Extreme Differences & Absolute & .113 \\
\cline { 2 - 3 } & Positive & .113 \\
\cline { 2 - 3 } & Negative & -.095
\end{tabular}




\begin{tabular}{ll}
\hline Kolmogorov-Smirnov $Z$ & .886 \\
\hline Asymp. Sig. (2-tailed) & .412 \\
\hline a. Test distribution is Normal. & \\
b. Calculated from data. & \\
\hline
\end{tabular}

Source: Processed Data (2020)

The statistical results presented in Table 9 show that the Kolmogorov Smirnof test obtained a significant value of 0.412 . This result means that the resulting significant value is higher than 0.05. So that the model in this study can be assumed to meet the rules of classical assumptions in fact that the data has been normally distributed.

Table 10 Analisys of Heteroscedasticity

\begin{tabular}{|c|c|c|c|c|}
\hline \multicolumn{5}{|l|}{ Coefficients ${ }^{a}$} \\
\hline \multirow[b]{3}{*}{ Model } & \multirow{2}{*}{\multicolumn{2}{|c|}{$\begin{array}{l}\text { Unstandardized } \\
\text { Coefficients }\end{array}$}} & \multirow[b]{3}{*}{$t$} & \multirow[b]{3}{*}{ Sig. } \\
\hline & & & & \\
\hline & $\bar{B}$ & Std. Error & & \\
\hline 1 (Constant) & .411 & .189 & 2.178 & .034 \\
\hline Motivation to graduate on-time & .035 & .067 & .517 & .607 \\
\hline Skills in writing scientific research & -.117 & .099 & -1.175 & 245 \\
\hline Quality of paper guidance & .045 & .101 & .449 & .655 \\
\hline
\end{tabular}

a. Dependent Variable: RES2

Source: Processed Data (2020)

The results of the Glejser test presented in Table 10 show that the significant value for the motivation variable to graduate on time is 0.607 where the value is higher than 0.05, so the motivation variable to graduate on time is free from heterocedasticity symptoms. Furthermore, for the variable of the ability to write scientific papers a significant value is obtained of 0.245 where the value is higher than 0.05 , it can be concluded that the variable of the ability to write scientific papers is free from heteroscedasticity indications. Moreover, for the variable of the quality of the final assignment guidance, it was obtained a significant value of 0.655 where the value is greater than 0.05 , so it can be concluded that the variable of the quality of final assignment guidance is free from heteroscedasticity indications. Thus, it can be 
concluded that the model in this study has met the classical assumptions and it can be stated that this model is suitable for use.

To see the significance of the contribution to the motivation variable to graduate on time, the ability to write scientific papers, and the quality of final assignment guidance for increasing graduation on time can be seen in the determination analysis in the following table.

Table 11 Coefficient of Determination

\begin{tabular}{lllll}
\hline \multicolumn{2}{l}{ Model Summary } & & & \\
\hline Model & $\mathrm{R}$ & $R$ Square & Adjusted $R$ Square & $\begin{array}{l}\text { Std. Estimate } \\
\text { Estor of the }\end{array}$ \\
\hline 1 & $.898^{\mathrm{a}}$ & .807 & .797 & .44697
\end{tabular}

a. Predictors: (Constant), Motivation to graduate on time, Capability to write scientific paper, quality of final task guidance

b. Dependent Variable: Final task complement

Source: Processed Data (2020)

On table 11 it has been proven that the coefficient of determination is 0.797 , which means that the magnitude of the influence given by the motivation to graduate on time, the ability to write scientific papers, and the quality of final task guidance on the completion of the final project is $79.7 \%$. Meanwhile, the remaining $20.7 \%$ is influenced by other variables not examined in this study. Analyzed from the results of the analysis partially, the dominant variable that has an influence on the completion of the final project is the quality of the final assignment guidance, where the resulting beta coefficient value is 0.544 .

Table 12 Analisys of F-Statistic

\begin{tabular}{lllllll}
\hline ANOVA $^{\boldsymbol{b}}$ & \multicolumn{1}{l}{ Sum } & of & & & \\
\hline \multirow{2}{*}{ Model } & Squares & $\boldsymbol{d} \boldsymbol{f}$ & Mean Square & $\boldsymbol{F}$ & Sig. \\
\hline 1 & Regression & 47.639 & 3 & 15.880 & 79.483 & $.000^{\mathrm{a}}$ \\
\cline { 2 - 7 } & Residual & 11.388 & 57 & .200 & & \\
\cline { 2 - 7 } & Total & 59.027 & 60 & & & \\
\hline
\end{tabular}


a. Predictors: (Constant), Quality of final task guidance, Motivation to graduate on time, Capability to write scientific paper

b. Dependent Variable: Final task completion

Source: Processed Data (2020)

The statistical results that being shown in Table 12 obtained a significant value of o.0oo. The statistical result obtained is lower than the standard measurement in this model, which is 0.05 . The result that can be concluded is that the hypothesis in this study is acceptable, with the conclusion that the quality of the final assignment guidance, motivation to graduate on time and the ability to write scientific papers have significant effect on the completion of the final task Department of Management students of STIE Mikroskil Medan.

The variable of student final assignment completion can be influenced by some variables, including the quality of student guidance to the supervisor. The quality of guidance in this context is how much it is possible for students and supervisors to be able to provide mutual understanding that can be integrated, so that in the process of completing student final task, quick completion can be applied.

\section{Table 13 Partial Analisys}

\section{Coefficientsa}

\begin{tabular}{|c|c|c|c|c|c|}
\hline \multirow[b]{4}{*}{ Model } & \multicolumn{3}{|c|}{ Unstandardized Standardized } & \multirow[b]{4}{*}{$\boldsymbol{t}$} & \multirow[b]{4}{*}{ Sig. } \\
\hline & \multicolumn{2}{|c|}{ Coefficients } & \multirow[t]{2}{*}{ Coefficients } & & \\
\hline & & Std. & & & \\
\hline & $\boldsymbol{B}$ & Error & Beta & & \\
\hline \multirow[t]{2}{*}{1 (Constant) } & -.368 & .265 & & - & .170 \\
\hline & & & & 1.389 & \\
\hline Motivation to graduate on time & .245 & .094 & .244 & 2.601 & .012 \\
\hline $\begin{array}{l}\text { Capability to write scientific } \\
\text { paper }\end{array}$ & .338 & .139 & .268 & 2.431 & .018 \\
\hline Quality of final task guidance & .544 & .142 & .455 & 3.838 & .000 \\
\hline
\end{tabular}

a. Dependent Variable: Final task completion

\section{Source: Processed Data (2020)}


From the results of the partial statistical analysis shown in Table 13, the multiple linear regression equation model can be described as:

Final Task Competion $=\quad-0,368+$ o,245 Motivasi Lulus Tepat Waktu + 0,338

Capability to Write Scientific Papers +o,544 Quality of Final Task Guidance

\section{The Effect of Motivation on Graduation on Time on Final Task Completion}

Analysis of the influence of motivation to graduate on time has been proven through hypothesis testing which shows that motivation to graduate on time can bridge influence on the completion of student final task. From these results, motivation is able to bring an influence on the completion of the final project in case that the indicators used were able to answer what the researcher really wants to investigate. These indicators include students who have high motivation to graduate on time because they want to get jobs. Students gave response that when students can quickly complete their studies, then the opportunities they will get to get a job is higher. However, unlike students who take the afternoon class schedule, evening class students do not have the motivation to get better jobs. This means that the majority of students who take the afternoon class schedule have been working in the company, so they have different motivations from morning class students whose activities are only studying in college.

The next indicator that is able to provide reinforcement in the motivation variable is the sense of pride of students when they are able to graduate on time. The students' response were that they had special pride if they could graduate on time and even graduate earlier. The next indicator is an award if students are able to graduate on time both from campus and from their family and friends. Moreover, the next indicator is the students' persistence in doing their final task. This indicator of persistence becomes a tough opponent for students. From the results of the interview process with students, the factor that most inhibited students from being able to complete their final projects on time was the lack of student persistence in doing their final tasks.

The results of this study are in line with the research conducted by Elista (2019) with the title "Research on the factors that affect the completion of thesis in students of the Geography Education Department Study Program”. The results of this study indicate that the motivation to graduate on time possess an effect on the completion of the final project of Department of Management students in STIE Mikroskil. 


\section{The Effect of the Capability to Write Scientific Papers on Final Task Completion}

The results of the partial hypothesis testing state that the ability to write scientific papers has an effect on the completion of the final project of students of STIE Mikroskil Management Study Program. From the results of the analysis, the ability to write scientific papers is factored by 6 reinforcing indicators. The first indicator is knowledge of scientific work. From the results of observations to students, the majority of students gave less agreeable responses, which means that there are still many students majoring in management who do not understand the scientific work. This matter can have an impact when there are still many students who do not understand the term scientific work. The first impact is the length of the student's final project process, and the next impact is the low quality of the scientific work created by these students.

The next indicator is about the writing experience of students in the field of scientific writing. From the results of student responses which can be illustrated through descriptive analysis, the majority of students answered disagree. This indicates that there are still many students majoring in management who have minimal experience in writing scientific papers, so this is one of the factors inhibiting students from doing their final project. The next indicator is the suitability of the title with the content of scientific work made by students, which shows that sometimes it is not suitable. This matter is caused by that the students still do not understand the titles they are researching and the relationship of the variables they are studying. Thus, this condition will make students in a difficult condition in doing their final assignments. The next indicator is about the ideas that are put into scientific writing, The choice of words used in their scientific papers are still in simple dictions and the ability of students to understand punctuation in scientific works is still limited. This is also caused by students comprehension that still low, where they even still do not understand what actually a work scientific is.

The results of this study are in line with the research conducted by Elista (2019) with the title "Research on the factors that affect the completion of thesis in students of the "Geography Education Department". The results of this study indicate that the ability to write scientific papers has an effect on the completion of the final project of STIE Mikroskil Management Department students. 


\section{Effect of Quality of Final Project Guidance on Final Task Completion}

The results of the partial hypothesis testing state that the quality of final assignment guidance has an effect on the completion of the final project management students majoring in STIE Mikroskil. On the results of the analysis it is also showed that the quality of final assignment guidance has direct relationship with the completion of the final project, where if the quality of student guidance with lecturers is improved, it will provide an increase in the completion of the final project of Management of Department students of STIE Mikroskil.

In addition, the results of the influence of the quality of the final task guidance are factored by some reinforcing indicators, including the suitability of the lecturer with the field of science, the quantity of student guidance with the supervisor, the suitability of what needs are expected when guidance process occurs, the situation during student guidance with the supervisor, techniques in the guidance process, and supporting equipment at the time of guidance. Of all the supporting indicators for the quality of the final assignment guidance, the average response to the indicators states that the perception is disagreeable. Among overall indicators, the very weak indicator is the quantity of student guidance. In this case, there are still many students whose guidance quantities in few. This matter definitely will affect the quality of the content of scientific works created by students.

The results of this study are in line with the research conducted by Elista (2019) with the title "Research on the factors that affect the completion of thesis in students of the Geography Education Department”. The results showed that partially the quality of the student's final assignment guidance had an effect on the completion of the student's final project Management Study Program STIE Mikroskil.

\section{The Influence of Motivation to Graduate on Time, Capability to Write Scientific Papers, Quality of Final Project Guidance on Final Task Completion}

From the results of the hypothesis analysis, the simultaneous analysis states that the motivation to graduate on time, the ability to write scientific papers, and the quality of final assignment guidance have effects on the completion of the final project management students of STIE Mikroskil. The results of this study are in line with the research conducted by Hartanto with the title of research "The factors that influence the completion of student thesis of students of the Accounting Education Program, Faculty 
of Economics, Yogyakarta State University. These results indicate that overall that the motivation to graduate on time, the ability to write scientific papers, and the quality of final assignment guidance affect the completion of the final project.

From the results of this study, it is also in line with the research conducted by Elista (2019) with the title "Research on the factors that affect the completion of a thesis final project in Geography Education Department students". The results of this study indicate that simultaneously the motivation to graduate on time, the ability to write scientific papers and the quality of final assignment guidance have an effect on the completion of students' final assignments.

\section{CONCLUSION}

From the overall results of this study, it is concluded that the motivation to graduate on time has a significant effect on the completion of students' final assignments. These results also indicate that the model formed between the motivation variables to graduate on time to the completion of the final project has an unidirectional relationship. This describes that when students increase their motivation in completing the final project, it will provide an increase in student graduation on time. Furthermore, it is also written on the variable ability to write scientific papers, it is found that the completion of students' final projects is influenced by the ability of students to write scientific papers significantly. From these results, it is also indicated that the model formed between the ability to write scientific papers and the completion of student final assignments has positive relationship. This matters describes that when students improve their abilities in writing scientific papers and also always train themselves to write scientific papers, the completion of student final assignments will also increase.

The next results also show that the quality of the final assignment guidance also contributes to the completion of students' final assignments. The quality of guidance also has a significant effect on completing students' final assignments. From these results also indicate that the model formed in this study regarding the quality of final assignment guidance to the completion of the final project has positive and unidirectional relationship. This matter shows that if the quality in the guidance of students and lecturers final assignments improves the process during guidance, it will provide an increase for the completion of the final assignment. Among the three variables in this study, to provide the largest contribution to the improvement of final project completion is the quality of final assignment guidance. 


\section{REFERENCES}

Arif S. Sadiman, dkk. Media Pendidikan, Pengertian, Pengembangan dan Pemanfaatannya.

Jakarta. PT. Raja Grafindo Persada. 2009.

Chukwuma, E.M.,Obiefuna, o. Effect of Motivation on Employe Productivity : A Study of Manufacturing Companies in Nnewi. Journal of Managerial Studies and Research. 2014. Nnewi.

Dalman, H. Keterampilan Menulis. Jakarta. PT. Raja Grafindo Persada. 2014.

Darmadi, Hamid. Metode Penelitian Pendidikan. Bandung. Alfabeta. 2011

Hamalik, Oemar. Proses Belajar Mengajar. Jakarta. Bumi Aksara. 2004.

Hidayati, Yulia Maftuhah. Pembelajaran Penjumlahan Bilangan Pecahan dengan Metode Contexual Teaching and Learning (CTL) di SD Muhammadiyah Program Khusus, Kota Barat. Surakarta. Junrnal Penelitian Humaniora, 12 (1), 86-94. 2012.

Kuncoro, Mudrajad. Metode Riset Untuk Bisnis dan Ekonomi. Edisi 4. Jakarta. Erlangga. 2013. Maslakhah, Siti, dkk. Bahasa Indonesia di SD. Jakarta. Universitas Terbuka. 2011

Siswanto, Ibnu, Sampurno, Yoga Guntur. Faktor-Faktor Penghambat Penyelesaian Tugas Akhir Skripsi Mahasiswa Pendidikan Teknik Otomotif FT UNY. E-Joernal.2013. Yogyakarta: FT UNY.

Sugihartono, dkk. Psikologi Pendidikan. Yogyakarta. UNY Press. 2012.

Sugiyono. Metode Penelitian Pendidikan Pendekatan Kuantitatif, Kualitatif, dan R\&D. Bandung. Alfabeta. 2013 